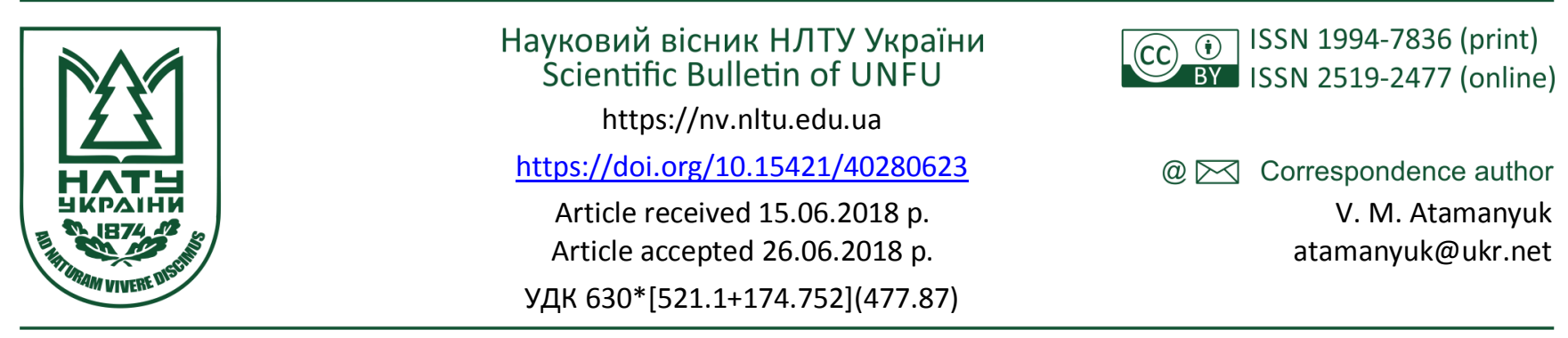

\author{
Д. М. Симак', В. М. Атаманюк², В. І. Склабінський' , А. О. Нагурський², Я. М. Гумницький² \\ ${ }^{1}$ Сумський державний університет, м. Суми, Украӥна \\ ${ }^{2}$ Національний університет "Львівська політехніка", м. Львів, Украйна
}

\title{
МЕТОДИКА РОЗРАХУНКУ ПРЯМОТЕЧІЙНО-ПРОТИТЕЧІЙНОГО РОЗЧИНЕННЯ КАЛІЙНОЇ РУДИ
}

\begin{abstract}
Наведено результати теоретичного та експериментального дослідження процесу розчинення калійної руди, основу якої складають сполуки калій хлориду та калій сульфату. Подано результати експериментального дослідження розчинення калійної солі у реакторі з механічним та пневматичним перемішуванням, який імітував одну з комірок промислового апарата. Фізично змодельовано цей процес у реакторі з механічним перемішуванням. Процес розчинення проведено за низьких чисел обертів, які становили 80 об/хв, що імітувало розчинення у промисловому шнековому апараті-розчиннику, у якому тверда фаза переміщається шнеком по дну апарата, а рідина рухається над поверхнею твердої фази, при цьому тверда фаза не переходить у зважений стан. Транспортування твердої солі шнеком перемішує ії та оновлює поверхню контакту солі з рідиною. Визначення коефіцієнта масовіддачі проведено під час розчинення калійної руди у насиченому розчині натрій хлориду за відсутності у ньому іонів калію, так і за їх наявності, що відповідає промисловим умовам розчинення і $€$ необхідною умовою розчинення для кристалізації калійної солі. Наведено основні параметри процесу розчинення калійної солі у насиченому розчині натрій хлориду. На основі рівняння масовіддачі визначено коефіцієнт масовіддачі під час механічного перемішування та пневматичного барботування розчину. Досліджено розчинення калійної солі за умов механічного перемішування та додаткової подачі нагрітого повітря. Наведено методики розрахунку системи апаратів-розчинників у протитечійно-прямотечійній схемі розчинення. Для промислового розчинника на основі рівнянь матеріального балансу та кінетики складено математичну модель, яка описує процес розчинення. Розглянуто систему трьох апаратів-розчинників, кожен $з$ яких розділений вертикальною перегородкою на дві комірки, що імітують реактор ідеального перемішування. У кожному апараті фази рухаються прямотечійно. У системі трьох апаратів рух твердої та рідкої фаз відбувається протитечійно. Рішення математичної моделі представлено у графічному вигляді.
\end{abstract}

Ключові слова: розчинення; масообмін; інтенсифікація; математична модель.

Вступ. Процеси розчинення набувають широкого застосування у хімічній, харчовій, природоохоронній технологіях. Розчинення - це процес переходу твердої фази до розчину і може супроводжуватись повним зникненням твердої фази. 3 кінетичної точки зору, розчинення може протікати у дифузійній, кінетичній чи змішаній областях. Розчинником може бути вода чи водні розчини кислот, лугів, солей. Широкого застосування розчинення набуло у галургії під час перероблення природних солей (Zdanovskyi, 1972; Akselrud \& Molczanov, 1977).

Наведені у літературних джерелах дані щодо розчинення стосуються окремих твердих частинок, або ансамблю монодисперсної твердої фази. Природні солі це складні полідисперсні суміші, які перед розчиненням підлягають подрібненню. У промислових умовах розчинення відбувається у апаратах-розчинниках. Широкого застосування набули шнекові горизонтальні розчинники, у яких транспорт твердої фази відбувається шнековим транспортером, а рідка фаза переміщується самотечією. Калійні солі є складною сумішшю солей, які також можуть розчинятись. У найбільшій кількості знаходиться галіт $\mathrm{NaCl}$.

Розрахунок апаратів-розчинників у випадку полідисперсної суміші $є$ значно складнішим порівняно з монодисперсною сумішшю, тому цій проблемі у літературі приділено недостатньо уваги. Окрім цього, представляє інтерес розчинення у газорідинному потоці, в якому інертна газова фаза виконує роль інтенсифікатора. Під час розчинення в апаратах періодичної дії змінюється

\section{Інформація про авторів:}

Симак Дмитро Михайлович, канд. техн. наук, здобувач. Email: dsymak13@gmail.com

Атаманюк Володимир Михайлович, д-р техн. наук, професор, завідувач кафедри хімічної інженерії. Email: atamanyuk@ukr.net; https://orcid.org/0000-0002-8707-2319

Склабінський Всеволод Іванович, д-р техн. наук, професор, завідувач кафедри процесів та обладнання хімічних та нафтопереробних виробництв. Email: sklabin@ukr.net

Нагурський Андрій Олегович, канд. техн. наук, асистент, кафедра хімічної інженерії. Email: nagurskiy@ukr.net

Гумницький Ярослав Михайлович, д-р техн. наук, професор, кафедра екології та збалансованого природокористування. Email: jgumnitsky@ukr.net; https://orcid.org/0000-0003-0464-9782

Цитування за ДСтУ: Симак Д. М., Атаманюк В. М., Склабінський В. І., Нагурський А. О., Гумницький Я. М. Методика розрахунку прямотечійно-протитечійного розчинення калійної руди. Науковий вісник НЛтУ України. 2018, т. 28, № 6. С. $117-121$.

Citation APA: Simak, D. M., Atamaniuk, V. M., Sklabinskyi, V. I., Nagurskiy, A. O., \& Gumnnitsky, Ya. M. (2018). Calculation methodology for potassium ore potentially-contracting dissolution. Scientific Bulletin of UNFU, 28(6), 117-121.

https://doi.org/10.15421/40280623

Науковий вісник НЛтУ України, 2018, т. 28, № 6 Scientific Bulletin of UNFU, 2018, vol. 28, no 6 
концентрація розчиненої речовини, що істотно впливає на рушійну силу процесу, змінюючи при цьому швидкість розчинення.

Аналіз останніх досліджень і публікаиій. Рівновагу та кінетичні закономірності розчинення наведено у (Akselrud \& Molczanov, 1977). Значну увагу в літературних джерелах приділено конкретним технологічним процесам, де основною стадією $є$ розчинення. Переважно розглянуто процеси одержання калійних добрив (Morgenstern, 2014; Khacevycz, Artus \& Kostiv, 2015; Khacevycz \& Kostiv, 2015), обов'язковою стадією яких є розчинення твердої фази. Цей процес $є$ складним через багатокомпонентність калійних солей, що враховують під час проведення розчинення. Розчинення належить до масообмінних процесів за участі твердої фази. Автори наукових робіт основну увагу приділяють дослідженню кінетики розчинення та інтенсифікації цього процесу. Масообміну у системах 3 твердою фазою присвячена робота (Symak, Atamaniuk \& Gumnitsky, $2015)$, де автори навели результати розчинення й експериментально визначений коефіцієнт масовіддачі порівнюють 3 теоретичним значенням, отриманим на основі теоретичного аналізу ізотропної турбулентності. Математичне моделювання нестаціонарних процесів розчинення розглянуто у (Babenko \& Ivanov, 2015), з урахуванням того, що процес розчинення належить до нестаціонарних, тому що у часі змінюються поверхня розчинення і концентрація речовини у рідині. Розчиненню полідисперсної твердої фази присвячено роботу (Melihov et al., 1989). Складний процес розчинення міді сульфату, яка знаходиться між інертними частинками, розглянуто у (Gumnitsky, Atamaniuk \& Symak, 2017). Цей процес об'єднує і розчинення, і екстрагування розчиненого компоненту 3 ансамблю пористих частинок. Аналогію розчинення та адсорбції наведено у (Sabadash et al., 2017).

У багатьох роботах порушено проблеми інтенсифікації масообміну у системах тверде тіло - рідина. Серед різних методів (Gumnytsky \& Symak, 2015; Gumnitsky, Yurym \& Osman, 1994) використовується інтенсифікація введенням у систему інертної газової фази. Цим методом можна досягти значного зростання коефіцієнта масовіддачі. У низці робіт виникнення інертної фази досягається внаслідок створення вакууму у системі, за якого генерується парова фаза (Gumnitsky \& Maystruk, 1999; Gumnytsky, Symak \& Nagurskyy, 2015; Gumnitsky, Yurym \& Venger, 2003). Утворення парових бульбашок відбувається на твердій поверхні солі і це руйнує пограничний дифузійний шар, що приводить до явища нестаціонарності, яке характеризується високими кінетичними коефіцієнтами.

Мета дослідження полягає у дослідженні процесу розчинення калійної руди, що містила калію сульфат та хлорид, та наведення методики розрахунку системи апаратів-розчинників у протитечійно-прямотечійній схемі розчинення.

Експериментальне дослідження. Експериментальне дослідження розчинення проводили у реакторі 3 механічним та пневматичним перемішуванням, який імітував одну з комірок промислового апарата. У промисловому реакторі розчинення відбувається в умовах перемішування твердої та рідинної фаз шнековим перемішувачем-транспортером. За цих умов тверда фаза знаходиться на дні реактора, а рідина омиває ії зверху. Транспортування твердої солі шнеком перемішує іiї та оновлює поверхню контакту солі з рідиною. Фізично змоделювали цей процес у реакторі з механічним перемішуванням за низьких чисел обертів, за яких рідина перемішувалась, а тверда фаза не переходила у зважений стан. У промислових умовах розчинення руди відбувається у насиченому по натрій хлориду розчині, розчинність якого мало залежить від температури. Водночас розчинність калій хлориду значною мірою визначається температурою і за умови зниження температури відбувається його кристалізація. За умови насиченого розчину натрій хлориду за температури $75{ }^{\circ} \mathrm{C}$ розчинність калій хлориду $C_{S}$ становить $235 \mathrm{\kappa} / \mathrm{m}^{3}$, або по іону $\mathrm{K}^{+} C_{S}=$ 133,5 кг/м ${ }^{3}$. Розсіюванням руди відбиралась фракція руди 3 середнім діаметром 3,0 мм. Густина руди становить $\rho_{S}=1950 \mathrm{\kappa г} / \mathrm{m}^{3}$. Коефіцієнт масовіддачі визначали під час розчинення калійної руди у насиченому розчині $\mathrm{NaCl}$ за відсутності у ньому іонів калію, так і за їх наявності, що відповідає промисловим умовам розчинення. Частота обертів перемішу вального пристрою становила $80^{ \pm 5} 1 /$ хв. Через певний час відбиралась проба рідини на аналіз іонів калію. 3 основного рівняння масовіддачі визначали коефіцієнт масовіддачі $\beta$ як величину, що характеризує інтенсивність процесу

$$
\beta=\frac{\Delta M}{F \cdot\left(C_{S}-\bar{C}\right) \cdot \Delta \tau},
$$

де: $\Delta M=W\left(C-C_{0}\right)-$ маса іонів калію, що розчинилась; $W$ - об'єм рідини в апараті; $C, C_{0}-$ кінцева та початкова концентрації іонів калію у розчині; $\bar{C}$ - середня концентрація іонів калію у розчині; $F$ - площа поверхні твердої фази; $\Delta \tau$ - тривалість розчинення.

Середню концентрацію іонів калію у розчині визначали як середньо-арифметичне між початковою концентрацією та кінцевою.

Визначене середнє значення коефіцієнта масовіддачі для чотирьох початкових концентрацій іонів калію у розчині дало змогу встановити, що коефіцієнти $\beta$ незначно відрізняються від середньоарифметичного значення, яке дорівнює $1,29 \cdot 10^{-5}$ м/с 3 похибкою 7,8 \%.

Дослідили вплив пневматичного перемішування на швидкість процесу розчинення калійної руди. На експериментальній установці у реактор подавалось через барботувальний пристрій повітря, попередньо нагріте до $75^{\circ} \mathrm{C}$. Частина твердої фази при цьому знаходилась у зваженому стані, що збільшувало контакт двох взаємодіючих фаз. Окрім цього, пневматичне перемішування впливає на коефіцієнт масовіддачі у бік його збільшення. Визначене експериментально значення коефіцієнта масовіддачі $\beta=2,15 \cdot 10^{-5} \mathrm{M} / \mathrm{c}$.

Експериментально визначені значення коефіцієнта масовіддачі можуть бути використані під час розрахунку процесів розчинення складних систем у багатостадійних технологічних схемах, які використовують у галургічних виробництвах.

Теоретичний розрахунок прямотечійно-протитечійного розчинення калійної руди. На рис. 1 наведено схему організації потоків твердої фази та рідини у системі $з$ трьох розчинників. Згідно із схемою у кожному розчиннику тверда і рідка фази рухаються в одному напрямку і реалізується прямотечійний рух. Разом 3 тим, у системі трьох апаратів- розчинників фази рухаються протитечійно. Кожен з апаратів розділений на дві частини вертикальними перегородками, які з певним наближенням перетворюють ці частини апарата у реак- 
тори ідеального перемішування. 3 урахуванням роздільних перегородок утворюється 6 окремих комірок. Нумерація комірок починається 3 комірки, в яку надходить свіжий розчин 3 початковою концентрацією $C_{n}$. Кінцевий розчин з максимальною концентрацією $C_{\kappa}$ виходить із шостої комірки. Тверда фаза у кількості $M_{0}$ подається у 5 комірку верхнього розчинника. Рух двох фаз у комірках 5 і 6 відбувається прямотечійно. Аналогічний рух фаз проходить у комірках 3 і 4 та комірках 1 i 2.

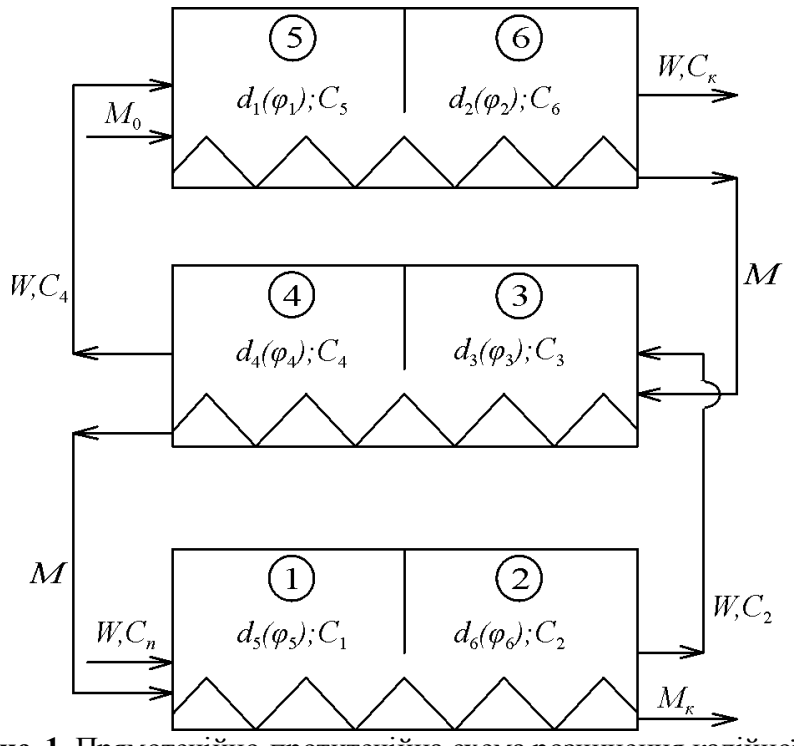

Рис. 1. Прямотечійно-протитечійна схема розчинення калійної руди

Таку складну схему руху потоків пояснюють масообмінним процесом, який значною мірою визначається рушійною силою, тобто різницею концентрацій. Прямотечійна схема дає змогу створювати великі рушійні сили та інтенсифікувати масообмін. Протитечійний рух дає змогу отримувати вищі кінцеві концентрації, що є важливим для технології розчинення.

Розрахунок процесу базується на кінетичних закономірностях, в основі яких знаходиться рівняння масовіддачі та матеріального балансу, які для першої комірки можуть бути записані так:

$$
-\frac{d M}{d \tau}=\beta \cdot F \cdot\left(C_{S}-C_{1}\right) ; \quad M_{4}-M_{5}=W_{c}\left(C_{1}-C_{n}\right) .
$$

У системі рівнянь (2): $C_{n}$ - початкова концентрація іонів калію у вихідному розчині, що надходить на розчинення 3 об'ємною витратою $W_{C} ; C_{1}$ - концентрація іонів калію у першій комірці; $M_{4}-$ масова витрата іонів калію, що надходить 34 комірки 3 твердою фазою; $M_{5}-$ масова витрата іонів калію, що залишає 5 комірку.

У системі (2) змінними є три величини: $M, F$ i $C$. Значення масової витрати $M$ та поверхню розчинення $F$ можна виразити через діаметр твердої фази. Кінетичне рівняння за такої заміни матиме такий вигляд:

$$
-\int_{d_{4}}^{d_{5}} d(d)=\frac{2 \beta}{\rho_{S}}\left(C_{S}-C_{1}\right) \cdot d \tau
$$

Після інтегрування отримуємо зміну розмірів частинок у першій комірці за час $\Delta \tau$ перебування у ній твердорідинної суміші

$$
d_{5}-d_{4}=\frac{2 \beta}{\rho_{S}}\left(C_{S}-C_{1}\right) \cdot \Delta \tau
$$

Для будь-якої комірки кінетичне рівняння може бути записане

$$
d_{i+1}=d_{i}-\frac{2 \beta}{\rho_{S}}\left(C_{S}-C_{j}\right) \cdot \Delta \tau .
$$

Відповідно рівняння матеріального балансу розчинення має такий вигляд:

$$
M_{i}-M_{i+1}=W\left(C_{j+1}-C_{j}\right) .
$$

Виразивши масу твердої фази через розміри частинок, рівняння (6) може бути записане

$$
N \cdot \rho_{S} \cdot \frac{\pi}{6}\left(d_{i}^{3}-d_{i+1}^{3}\right)=W\left(C_{j+1}-C_{j}\right),
$$

де: $N$ - число частинок.

Розрахунок потрібно виконувати для 6 комірок, у яких концентрація рідкої фази $C$ поступово змінюється від 1 до 6 комірки, а діаметр частинок $d$, який представляє тверду фазу, у такій послідовності комірок: $5 ; 6 ; 3$; $4 ; 1 ; 2$.

Введемо безрозмірний розмір твердих частинок $\phi_{i}=d_{i} / d_{0}$. Кінетичне рівняння (5) запишемо

$$
\phi_{i+1}=\phi_{i}-A\left(C_{S}-C_{j}\right) \text {, }
$$

де постійна $A=\frac{2 \beta \cdot \Delta \tau}{\rho_{S} \cdot d_{0}}$.

Балансове рівняння (7) з урахуванням безрозмірного розміру $\phi$ матиме такий вигляд:

$$
\phi_{i}^{3}-\phi_{i+1}^{3}=B\left(C_{j+1}-C_{j}\right) .
$$

Постійна $B=\frac{6 W}{N \cdot \pi \cdot \rho_{S} \cdot d_{0}^{3}}$.

Згідно $з$ рівнянням (8), отримуємо систему рівнянь для визначення безрозмірного параметра $\phi_{i}$ для шести комірок, рухаючись від першої комірки до шостої

$$
\begin{array}{ll}
\phi_{1}=\phi_{0}-A\left(C_{S}-C_{5}\right) ; & \phi_{2}=\phi_{1}-A\left(C_{S}-C_{6}\right) ; \\
\phi_{3}=\phi_{2}-A\left(C_{S}-C_{3}\right) ; & \phi_{4}=\phi_{3}-A\left(C_{S}-C_{4}\right) ; \\
\phi_{5}=\phi_{4}-A\left(C_{S}-C_{1}\right) ; & \phi_{6}=\phi_{5}-A\left(C_{S}-C_{2}\right) .
\end{array}
$$

Останнє рівняння системи (10) визначає ступінь розчинення $\eta$

$$
\eta=\frac{M_{0}-M_{k}}{M_{0}}=1-\phi_{6}^{3}
$$

Використовуючи рівняння (9), складаємо другу систему з шести рівнянь

$$
\begin{array}{ll}
\phi_{0}^{3}-\phi_{1}^{3}=B\left(C_{5}-C_{4}\right) ; & \phi_{1}^{3}-\phi_{2}^{3}=B\left(C_{6}-C_{5}\right) ; \\
\phi_{2}^{3}-\phi_{3}^{3}=B\left(C_{3}-C_{2}\right) ; & \phi_{3}^{3}-\phi_{4}^{3}=B\left(C_{4}-C_{3}\right) ; \\
\phi_{4}^{3}-\phi_{5}^{3}=B\left(C_{1}-C_{n}\right) ; & \phi_{5}^{3}-\phi_{6}^{3}=B\left(C_{2}-C_{1}\right) .
\end{array}
$$

3 рівняння (12) визначаємо значення концентрацій $C$ та підставляємо у систему рівнянь (10). Отримуємо систему з 6 рівнянь із 6 невідомими значеннями відносного діаметра $\phi$. Концентрація насичення $C_{S}$ та початкова концентрація $C_{n}$ є відомими. Кінцева система, яка підлягає рішенню, має такий вигляд:

$$
\begin{aligned}
& \phi_{1}=1-A\left(c_{s}-c_{n}\right)+\frac{A}{B}\left(1-\phi_{1}^{3}+\phi_{2}^{3}-\phi_{6}^{3}\right) ; \\
& \phi_{2}=1-2 A\left(c_{s}-c_{n}\right)+\frac{A}{B}\left(2-\phi_{1}^{3}+\phi_{2}^{3}-2 \phi_{6}^{3}\right) ; \\
& \phi_{3}=1-3 A\left(c_{s}-c_{n}\right)+\frac{A}{B}\left(2-\phi_{1}^{3}+2 \phi_{2}^{3}-\phi_{3}^{3}+\phi_{4}^{3}-3 \phi_{6}^{3}\right) ; \\
& \phi_{4}=1-4 A\left(c_{s}-c_{n}\right)+\frac{A}{B}\left(2-\phi_{1}^{3}+3 \phi_{2}^{3}-\phi_{3}^{3}+\phi_{4}^{3}-4 \phi_{6}^{3}\right) ; \\
& \phi_{5}=1-5 A\left(c_{s}-c_{n}\right)+\frac{A}{B}\left(2-\phi_{1}^{3}+3 \phi_{2}^{3}-\phi_{3}^{3}+2 \phi_{4}^{3}-\phi_{5}^{3}-4 \phi_{6}^{3}\right) ; \\
& \phi_{6}=1-6 A\left(c_{s}-c_{n}\right)+\frac{A}{B}\left(2-\phi_{1}^{3}+3 \phi_{2}^{3}-\phi_{3}^{3}+3 \phi_{4}^{3}-\phi_{5}^{3}-5 \phi_{6}^{3}\right) .
\end{aligned}
$$


Провели розрахунок процесу прямотечійно-протитечійного розчинення згідно з промисловими даними, а саме діаметра частинок $3 \cdot 10^{-3} \mathrm{M}$; початкової концентрації $C_{n}=30 \mathrm{\kappa г} / \mathrm{M}^{3}$; концентрації насичення $C_{S}=124$ кг $/ \mathrm{m}^{3}$. Визначене експериментально значення коефіцієнта масовіддачі, що прийняте у розрахунках, $\beta=2,15 \cdot 10^{-5}$ м/с. Розрахунок проводили для масової витрати твердої фази $M_{0}=4 \mathrm{\kappa г} / \mathrm{c}$; об'ємна витрата рідкої фази $W=$ $0,08 \mathrm{~m}^{3} / \mathrm{c}$. Постійні величини $A=0,00132 ; B=0,02 ; A / B=$ 0,066 . Проведені теоретичні розрахунки наведено на рис. 2 у вигляді залежності відносного діаметра твердої фази $\phi_{i}$ від кількості комірок розчинника. Як видно 3 наведеної кривої 1 , кінцеве значення $\phi_{6}$ дорівнює 0,4 . Це означає, що ефективність цього розчинення $\eta=0,936$, що становить задовільний результат.

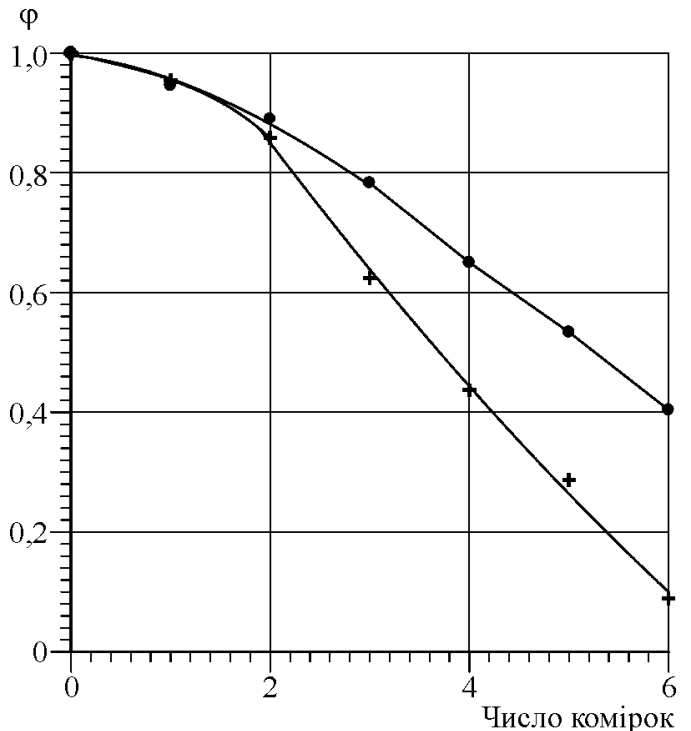

Рис. 2. Залежність відносного діаметра твердої фази $\phi_{i}$ від кількості комірок розчинника: 1) розчинення виключно механічним перемішуванням; 2) розчинення механічним перемішуванням та введенням нагрітого повітря

Подача нагрітого повітря у систему тверде тіло - piдина сприяє інтенсивному перемішуванню середовища та збільшенню коефіцієнта масовіддачі. Для умов лабораторного досліду коефіцієнт масовіддачі збільшився і становив величину $2,15 \cdot 10^{-5} \mathrm{~m} / \mathrm{c}$. Для цих умов визначено параметр $A=0,0022$; параметр $B=0,02$ i $A / B=0,11$. Проведені розрахунки згідно 3 моделлю розчинення (13) наведено на рис. 2 (крива 2) і показують зростання ефективності розчинення, коли кінцеве значення від- носного діаметра твердої фази становить $\phi_{6}=0,0894$, а ефективність розчинення дорівнює $0,9993$.

\section{Перелік використаних джерел}

Akselrud, G. A., \& Molczanov, A. D. (1977). Rastvoreniye tviordyh veshczestv. Moscow: Khimia. 272 p.

Artus, M. I., Kostiv, I. Yu. (2015). Polimineralni kaliyno-magniyevi rudy $\mathrm{v}$ oborotnyh shenitovyh rozczynah. Khim.prom.Ukrainy, 6(125), 39-43. [In Ukrainian].

Babenko, Yu. Y., \& Ivanov, E. V. (2015). Vlyianye nestatsyonarnykh effektov na skorost rastvorenyia odynochnoi chastytsy. Teor. osnovy khym. tekhn., 47(6), 624-629. [In Russian].

Gumnitsky, J., \& Maystruk, I. (1999). Intensifikaciya procesu fizycznoho rozczynennia u trohfazniy systemi pry rozridzhenni. Khim.prom.Ukrainy, 2, 23-26. [In Ukrainian].

Gumnitsky, J., Atamaniuk, V., \& Symak, D. (2017). Kinetyka ekstrahuvannia midi sulfatu $\mathrm{z}$ porystych czastynok. Integr. technol.ta energozbererzennia, 4, 23-27. [In Russian].

Gumnitsky, J., Yurym, M., \& Osman, A. (1994). The transfer during dissolring solids in condition of gas supply and in vacuum. Konferencija naukowa Inzenerija chemiczna. Vol. 1, (pp. 319326). Krakow.

Gumnitsky, J., Yurym, M., Venger, L. (2003). Kinetyka ekstrahuvannia cilovoho komponentu z poodynokoho kapilaru $\mathrm{v}$ umovah vakuumuvannia systemy. Visnyk $N U$ "Lvivska politechnika", 488, 220-222. [In Ukrainian].

Gumnytsky, Ya. M., Symak, D. M. (2015). Intensyfikatsiia masoobminnykh protsesiv u systemi tverde tilo - ridyna vvedenniam hazovoi fazy. Materialy XVIII Mizhnarodnoi naukovo - praktychnoi konferentsii, 1, 34-35. [In Ukrainian].

Gumnytsky, Ya. M., Symak, D. M., \& Nagurskyy, O. A. (2015). Rozczynennia tverdyh til $\mathrm{u}$ trohfazniy systemi utvoreniy vakuumuvanniam. Naukovi praci ONAChT, 47(1), 130-133.

Khacevycz, O. M., Artus, M. I., \& Kostiv, I. Yu. (2015). Bezkhlorne kaliyne dobryvo. Tekhnologia konversiyi mirfbilitu $\mathrm{z}$ kaliy khlorydom. Khim.prom.Ukrainy, 3(128), 37-41. [In Ukrainian].

Melihov, I. V., Dolgonosov, B. M., Elenin, G. G., \& Sosnin, N. V. (1989). Rastvoreniye polidispersnoy tverdoy fazy v plotnom sloye. Teor. Osnovy khim. Tehnologii., 23(1), 101-104. [In Russian].

Morgenstern, L. A. (2014). Proces poluczenia chlorida kaliya metodom razlozheniya karnalita vodoy. TOKHT, 48(1), 122-124. [In Russian].

Sabadash, V., Mylanyk, O., Matsutska, O., \& Gumnytsky, J. (2017). Kinenic regularities of copper ions adsorption by natural zeolite. Chemistry \& Chemical Technology. 11(4). 459-462.

Symak, D., Atamaniuk, V., \& Gumnitsky, Ya. (2015). Analysis of dissolution kinetics dased on the lokal isotropic turbulence theory. Chemistry \& Chemical Technology, 9(4), 493-497.

Zdanovskyi, A. B. (1972). Galurgia. Leningrad: Khimia. 528 p. [In Russian].

\section{Д. М. Сымак', В. М. Атаманюк², В. И. Склабинский1, А. О. Нагурский², Я. М. Гумницкий² \\ Сумской государственный университет, г. Сумы, Украина \\ ${ }^{2}$ Национальный университет "Львовская политехника", г. Львов, Украина}

\section{МЕТОДИКА РАССЧЕТА ПРЯМОТОЧНО-ПРОТИВОТОЧНОГО РАСТВОРЕНИЯ КАЛИЙНОЙ РУДЫ}

Приведены результаты теоретического и экспериментального исследования процесса растворения калийной руды, основу которой составляют соединения хлорида калия и калий сульфата. Представлены результаты экспериментального исследования растворения калийной соли в реакторе с механическим и пневматическим перемешиванием, который имитировал одну из ячеек промышленного аппарата. Физически смоделирован данный процесс в реакторе с механическим перемешиванием. Процесс растворения проведен при низких числах оборотов, которые составляли 80 об/мин, что имитировало растворение в промышленном шнековом аппарате-растворителе, в котором твердая фаза перемещается шнеком по дну аппарата, а жидкость движется над поверхностью твердой фазы, при этом твердая фаза не переходит во взвешенное состояние. Транспортировка твердой соли шнеком перемешивает ее и обновляет поверхность контакта соли с жидкостью. Определение коэффициента массоотдачи проводили во время растворения калийной руды в насыщенном растворе хлорида натрия при отсутствии в нем ионов калия, так и при их наличии, что соответствует промышленным условиям растворения и является необходимым условием растворения с целью кристаллизации калийной соли. Приведены основные параметры процесса растворения калийной соли в насыщенном растворе хлорида натрия. На основе уравнения массоотдачи определен коэффици- 
ент массоотдачи при механическом перемешивании и пневматическом барботировании раствора. Исследовано растворение калийной соли в условиях механического перемешивания и дополнительной подачи нагретого воздуха. Приведены методики расчета системы аппаратов-растворителей в противоточно-прямоточной схеме растворения. Для промышленного растворителя на основе уравнений материального баланса и кинетики составлена математическая модель, описывающая процесс растворения. Рассмотрена система трех аппаратов-растворителей, каждый из которых разделен вертикальной перегородкой на две ячейки, имитирующие реактор идеального перемешивания. В каждом аппарате фазы движутся прямоточно. В системе трех аппаратов движение твердой и жидкой фаз происходит противоточно. Решение математической модели представлено в графическом виде.

Ключевые слова: растворение; массообмен; интенсификация; математическая модель.

D. M. Simak', V. M. Atamaniuk², V. I. Sklabinskyi' , A. O. Nagurskiy', Ya. M. Gumnnitsky²

${ }^{1}$ Sumy State University, Sumy, Ukraine

${ }^{2}$ Lviv Polytechnic National University, Lviv, Ukraine

\section{CALCULATION METHODOLOGY FOR POTASSIUM ORE POTENTIALLY-CONTRACTING DISSOLUTION}

The authors present the results of theoretical and experimental studies of the dissolution of potassium ore, the compounds of potassium chloride and potassium sulfate being its basis. The results of an experimental study of the dissolution of potassium salt in a reactor with mechanical and pneumatic mixing, simulating one of the cells of the industrial apparatus, are presented. This process is physically simulated in a reactor with mechanical mixing. The dissolution process was carried out at low rotational speeds of 80 turns $/ \mathrm{m}$, which simulated dissolution of the salt in an industrial solvent-screw unit, in which the solid phase is moved by a screw on the bottom of the apparatus, and the liquid moves above the surface of the solid phase, while the solid phase does not pass into weighted state. The transport of solid salt with a screw mixes it and renovates the contact surface of the salt with the liquid. Determination of the coefficient of mass deduction was carried out during the dissolution of potassium ore in a saturated solution of sodium chloride in the absence of potassium ions in it, and in their presence, which corresponds to the industrial conditions of dissolution and is a necessary condition for dissolution in order to crystallize potassium salt. The main parameters of the dissolution of potassium salt in a saturated solution of sodium chloride are given. On the basis of the mass deduction equation, the coefficient of mass deduction during the mechanical mixing and the pneumatic bubbling of the solution was determined. The dissolution of potassium salt was investigated in conditions of mechanical mixing and with additional supply of heated air. The methods of calculating of the system of solvent apparatus in the counterflow-directly scheme of dissolution are presented. For an industrial solvent, based on the equations of material balance and kinetics, a mathematical model was compiled that describes the dissolution process. The system of three solvent apparatus, each of which is divided with vertical partition into two cells, imitating a perfect mixing reactor, is considered. In each apparatus, the phases move directly. In the system of three apparatus, the motion of solid and liquid phases is counterflow. The solution of the mathematical model is represented in the graphical form.

Keywords: dissolution; mass exchange; intensification; mathematical model. 